\title{
ハチ毒中のグルタミン酸アンタゴニスト
}

八チ毒といえばすぐ思い浮かぶのは，ミッバチやスズ メバチなどの社会生活を営むバチの毒だろら．これらの 八チにとって毒は外敵から巣を守るための武器で, 細胞 膜に作用するペプチドをはじめ, 生体アミンや酵素など の “カクテル”としてさまざまな作用を発揮する(1). こ れに対して, カリウドバチ (狩人蜂) と呼ばれるベッコ ウバチやジガバチなどは, 大きな巣をつくらず単独で生 活し，その毒は幼虫の慨を捕獲するために使われる.す なわち, クモや他の昆虫を毒で麻疩させてから卵を生み つけ, 睬化した幼虫は麻瘦したままの獲物を食べて成長 する.したがって, これらの八チの毒液中には, 神経伝 達阻害物質が含まれていることが予想されていた。事 実, T. Piek らは, カリウドバチの一種であるPhilanthus triangulum から 4 つの毒成分 $\alpha-, \beta-, \gamma-, \delta$-philanthotoxin を分離し，それらが昆虫のグルタミン酸レセプタ 一に対するアンタゴニストであることを報告した ${ }^{(2)}$. L-グルタミン酸は, 昆虫・甲殼類 の運動神経や哺乳類中枢神経系の主 要な興奮性伝達物質と考兄られてい る. 特に, 哺乳動物においてグルタ ミン酸レセプターは, 記憶や学習な どの高次脳機能や，てんかんをはじ めとするいろいろな神経疾患と深く 関わっていることがわかってきた. そのため, 近年, グルタミン酸レセ プターをめぐるさまざまな研究が世 界中で活発に行なわれ, 中でも, 特 異的で活性の高いアンタゴニストの 開発は, 神経生物学の基礎研究のた めだけでなく，医薬品への応用も期 待され, 重要なもののひとつとなっ ている.
P.triangulum のグルタミン酸アンタゴニストは, 最 近, 中西香爾ら ${ }^{(3)}$ と T. Piek ら ${ }^{(4)}$ にっってそれぞれ独立 に単離・構造決定された、これは, 八チ毒中のグルタミ ン酸アンタゴニストとして構造が明らかになった最初の 例である. 筆者は, コロンビフ大中西グループでこの研 究に関わる機会を得たので, その経過 ${ }^{(5)}$ と, その後の進 展 ${ }^{(6,7)}$ について紹介したい.

\section{Philanthotoxin の単離と構造決定}

P. triangulum は, 古くからその生態や習性がよく研 究されているハナスガリの一種で, ヨーロッパからアフ リカにかけて分布する、ミッバチだけを獲物として狩る ので, 別名八チオオカミ (bee wolf) とも呼ばれ, 養蜂 家からは嫌われている(8). この八チは集団で営巣するの で, しばしば大量に見つかることがある. 1986 年の夏, サハラ砂漠の Dakhla オアシスといらところで大発生

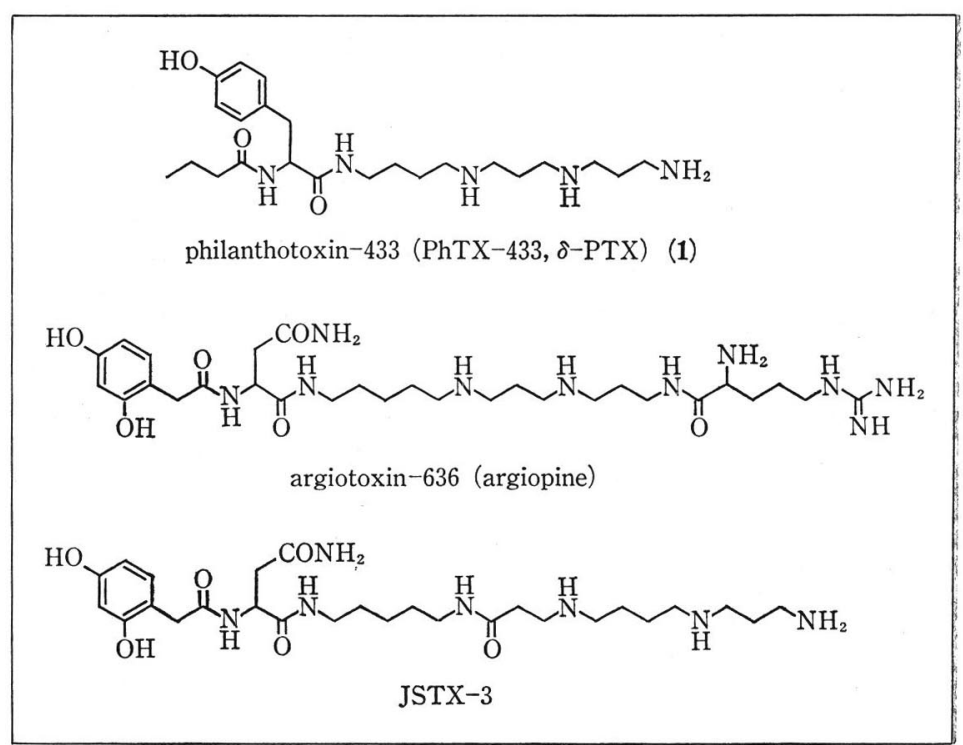

図 1 
し，7,000 匹のメスが採集された. 構造研究は, そのららの 1,000 匹 を使って行なった. バイオアッセイ 飞は, 当初ミッバチを使い, 麻痺さ せる方法を用いていたが，この方法 忏不適当であることがやがてわかっ た、それは，分離すると活性がなく なるが，すべての分画を合わせると また活性が現われる, すなわち, 複 数の成分の協同作用によって活性が 発現されるからである、バッタの足 の筋肉（神経筋接合部）を用いた電 気生理学的方法だとそのようなこと はなく，粗抽出物でも，分離したフ ラクションでも, 電気刺激したとき の筋肉の収縮をよく抑制した。な お。，この神経筋標本は Usherwood らによって詳しく研究され，グルタ ミン酸が興奮性神経伝達物質である ことが確立されているものである.

主成分である philanthotoxin-433 (PhTX-433 ; 数字はポリアミン部 の窒素間のメチレン数）は 1 匹当り

約 $1 \mu \mathrm{g}$ の収量で比較的簡単に単離でき, 構造は $\mathbf{1}$ と決 定した(図 1). 絶対配置は, 天然型のL型である.これは, Piek らが $\delta$-philanthotoxin( $\delta$-PTX) と呼んでいたもの と同じであった。ポリアミン部の構造については，3つ の可能な構造 PhTX-433 (1), -343 (2), -344 (3) が スペクトルで判別できなかったため，すべてを合成して 決定したが(スキーム $1 ， 2$ )，後にメタステーブルイオ ンを利用したマススペクトル（B/E linked scan MS） を用いて容易に区別できることがわかった。

このようにアシル基/アミノ酸/ポリアミンがつながっ た構造は，クモ毒中のグルタミン酸アンタゴニストと共 通のものである.クモも慨を捕獲するために毒を使ら が，その中からアシルポリアミンの基本骨格をもつもの が，最近続々と見つかっている．JSTX-3， argiotoxin636 (argiopine)（図 1) はその代表的なもので，それぞ れ日本産のジョロウグモ，ヨーロッパ産のコガネグモ類 から得られた.やはり強力なグルタミン酸アンタゴニス トなので, 今後の発展が注目されている ${ }^{(9,10)}$.

\section{Philanthotoxin の薬理学的性質}

多くの神経レセプターがそうであるように，グルタミ ン酸レセプターにもいくつかのサブタイプがあることが 知られている. 大別すると，イオンチャンネル共役型 (ionotropic) とG蛋白共役型 (metabotropic) で, 前者 はさらにアゴニストの選択性に基づいて NMDA*，キス カル酸 (AMPA), カイニン酸型の 3 つに細分化される. 過去 5 年ぐらいの間に, これらレセプターサブタイプの クローニングが盛んに行なわれ，分子としての実体がか なり明らかになってきたが(11)，レセプター蛋白そのもの は, 末だ精製されてはいない, 薬理学的には, NMDA レセプターに関する研究が最も進んでいて, それは，こ のサブタイプに特異的なアンタゴニストが早くから見つ けられていたことが大きな理由のひとつであろう。した がって, キスカル酸, カイニン酸型（まとめて non-

* 本号 726 頁「神経伝達物質グルタミン酸の受容体と神経細胞 死」を参照. 
NMDA 型と呼ぶこともある)レセプターに対しても， 選択性の高いアンタゴニストの開発が切望されている. バッタ神経筋標本のグルタミン酸レセプターは, ほ济キ スカル酸型であることがわかっているので, PhTX-433 はこのサブタイプに選択性が高いものと思われた.

そこで, PhTX-433 の薬理学的性質について詳しく検 討した. その結果は, 期待に反してサブタイブ選択性が なく, 程度の差はあるものの, イオンチャンネル共役型 の3つに対して同じようにアンタゴニストとして㗢くこ とがわかった、さらに,グルタミン酸レセプターだけで なく、ニコチン性アセチルコリンレセプターにも同様に 作用することが明らかになった. メカニズム的には、イ オンチャンネルが開いた状態作用する，いわゆるチャ ンネルブロッカーの性質を示した。より詳細汇調べてい くと, 濃度によって異なった作用を示すとりら與味深い 結果が得られた.すなわち，高濃度 $\left(10^{-4} \sim 10^{-7} \mathrm{M}\right)$ で はアンタゴニストであるが, 低濃度 $\left(10^{-9} \sim 10^{-11} \mathrm{M}\right)$ で は逆作用を増強する，これは，PhTX とレセプターの 結合部位が少なくとも 2 個所は存在することを示唆する.

\section{構造-活性相関}

このような PhTX の分子レベルでの詳しい作用メカ ニズムを調べるため，また PhTX を使ってレセプター 蛋白の精製, あるいはレセプターの 3 次元構造を明らか にすることを目指し，次に構造一活性相関を検討するこ とにした.クモ毒についても同様な研究が進んでいる が, PhTX は構造的により簡単なので, 合成しやすく, 誘導体もつくりやすいという利点がある. 誘導体の合成 は, 基本的にはスキーム 1 亿示した方法を踏襲し, 必要 に応じて多少変更した. 構造決定のために合成した $2 つ$
までに 100 種類に及ぶ誘導体が合成され，それぞれバッ タ神経筋 (キスカル酸型ダルタミン酸レセプター) を用 いた電気生理学, シビレエイ発電器官(ニコチン性アセ チルコリンレセプター) とラット大脳皮質 (NMDA 型 グルタミン酸レセプター)を用いたレセプター結合実験 によって活性が測定された. 構造一活性相関は，抒およ そどのレセプターについても同様の傾向を示したので, 以下にバッタ神経筋標本での結果を代表例として要約す る.

1) region I： ポリアミンはスペルミン程度の長さ が必要で，短くなると活性は著しく低下する，窒素を 完全メチル化して四級アンモニウムにしてもやはり低 下するが，ポりアミンの中央部にアルキル基を枝分か れさせると，数倍強い活性を示すようになる。

2) region II : ポリアミンの末端の窒素をアシル化 すると活性㤦低下するが，塩基性アミノ酸のリジン， アルギニンを結合させたものは $2 \sim 4$ 倍強くなる.

3) region III : 親油性基 (hydrophobic group) が 重要で, $\mathrm{C}_{10}$ の飽和脂肪酸, ベンゾイル基などにする と 10 倍近く活性が上昇する. 反対に, アスパラギン 酸などの親水性基 (hydrophilic group) は活性を低下 させる.

4) region IV： チロシンを他の芳香族アミノ酸に変 えると数倍活性が上がる.フェノール環にハロゲン， 特にヨウ素を入れても同様の效果がある、な牧, チロ シンを $\mathrm{D}$ 型にしても天然型と同等の活性を示す.

このように, 単独の構造変換で天然物より活性の高い 誘導体が得られたが，さらに，2個所を同時に変えると 相乗効果があることがわかった、特に, region II とIV の場合に著しく，化合物 4 (図 3) は, これまでに得ら の誘導体 2,3 の活性は 1 のそれと大 差ないことから, すなわち $\mathrm{PhTX}$ 343 を基本骨格として使うことにし た.とらすることによってポリアミ ン部の合成の手間が省け，より容易 に合成できるからである.

構造変換には PhTX を便宜的に 4つの部分 (region I〜IV) に分け （図 2），まず1個所だけを変えたも のをつくり，それから2 個所以上組 み合わせていく方針をとった，現在

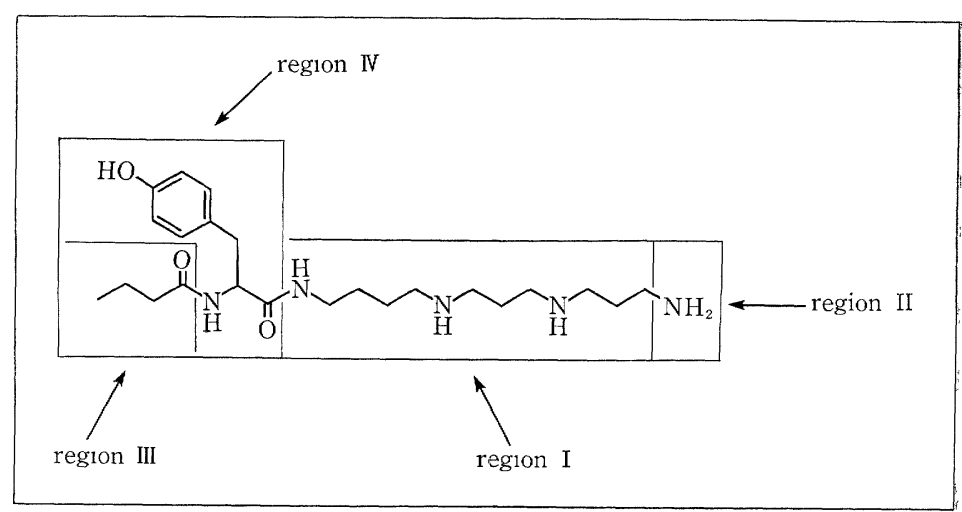

図 2 
れた誘導体で最も活性が高く， PhTX-433 の 33 倍の比活性があ る. 3 個所同時に構造変換したもの では, 化合物 $\mathbf{5}$ が 13 倍の比活性を 示した. また, PhTX と argiotoxin の混合型 (hybrid) 誘導体も合成さ れた ${ }^{(12)}$. この場合, ポリアミン部 が argiotoxin 型の6 では, 活性が PhTX-433 の数倍で, argiotoxin636 とは同程度であるが, PhTX 型 の 7 では著しく低下する.

以上の構造-活性相関の研究は, 所期の目的をかなり果たしたものと いえる. 第一に, PhTX とレセプタ 一の相互作用にとって重要な要素が 明らかになったことは, 分子レベル での活性発現のメカニズムを考光る 上で大きな手掛かりとなる，第二 に,フェノール環にヨウ素を入れる と活性が上がることは， ${ }^{125}$ 【を用い た放射性誘導体の合成を可能にす る. 第三に, 5 のようにフェニルア ジド基を持つものは，光アフィニテ ィーラベル (photoaffinity labeling) をするための良いリガンドとなり得 る. したがって, PhTX 誘導体は, 比較的均一なサブタイプで構成され る神経膜からのレセプター蛋白の精 製や，精製されたレセプター蛋白の 3 次元構造の解明に有用なるのになると考兄られる.

\section{Philanthotoxin を利用した光アフィニティ}

\section{ーラベル}

実際，化合物 5 を使って光アフィニティーラベルが可 能なことが確かめられたＰＰTT の阻害作用は可逆的 で，たとえばバッタ神経筋に作用させた後，標本をりン ゲル液で洗うと，活性はやがて回復する，それは，誘導 体の 5 汇ついても同でである。ところが，5 を作用させ ながら光を当てると，阻害は不可逆的になってしまう． このことは，アジド基が光の作用でニトレンを発生し， それがレセプターと共有結合した一光アフィニティ
ーラベルされた一一ためと考兄られる.

一方, 精製されたレセプター蛋白を用いてラベル化 し，その後，ペプチドマッピングなぞを行なえば，リガ ンド結合部位の 3 次元構造が解析できる.シビレェイ電 気器官から得られるニコチン性アセチルコリンレセプタ 一を用いて，その予備実験が行なわれた。このレセプタ 一は, 現在のところ, 神経レセプターの中では最も研究 が進えでいて，分子量約 27 万， 5 つのサブニニット $\alpha, \alpha^{\prime}, \beta, \gamma, \delta$ が花びらのように並び，その中心にイオ ンチャンネルが形成されると考允られている(13)， ${ }^{125} \mathrm{I} て ゙$ 放射ラベルした 5 を用いた光アフィニティーラベルの結 果から，PhTX はチャンネルの奥深く，細胞質に近いと 
ころに結合していると推定された，構造一活性相関を考 え合わせることにより，ポリアミンがチャンネルの内部 水入り込反，芳香環と脂肪族側鎖が細胞質側飞突き出 て, hydrophobic な相互作用によって固定しているよう なモデルが想定されている. グルタミン酸レセプター 峙まだ，いずれのサブタイプも精製されていないが， 将来それが達成されれば，同様な手法を用いて立体構造 の解析が可能になる。

$\mathrm{PhTX}$ 誘導体を用いた光アフィニティーラベルのも らひとつの利点は, 分子中のいろいろな位置にラベル試 薬を結合できることにある，たとえば，化合物 8 がすで に合成されているが(14)，このような誘導体を使光ば，5 を用いた場合とは違う場所をラベルすることができ，そ れらの結果を総合すると、より詳細な解析ができること になる、いずれにしても，PhTX 誘導体は，レセプター の精製・立体構造解明に有効なことがわかり, 今後の研 究の進展が期待される.

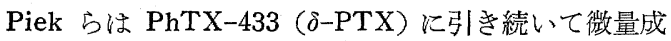
分として $\beta$-philanthotoxin ( $\beta$-PTX) を単離し, その構 造を9 と決定した ${ }^{(15)}$ (図 4). 9 も PhTX-433 と同様汇 チャンネルブロッカーの性質を示すが, メカニズムの詳 細は多少異なるようである。また，彼らは以前から， PhTX-433 がシナプス終末での グルタミン酸再吸収を 抑制する作用も併世持つことを報告している。やはり， いくつかの誘導体を合成していて, フェノール基をトリ フルオロメチル基に変えた化合物 10 が，PhTX-433 の

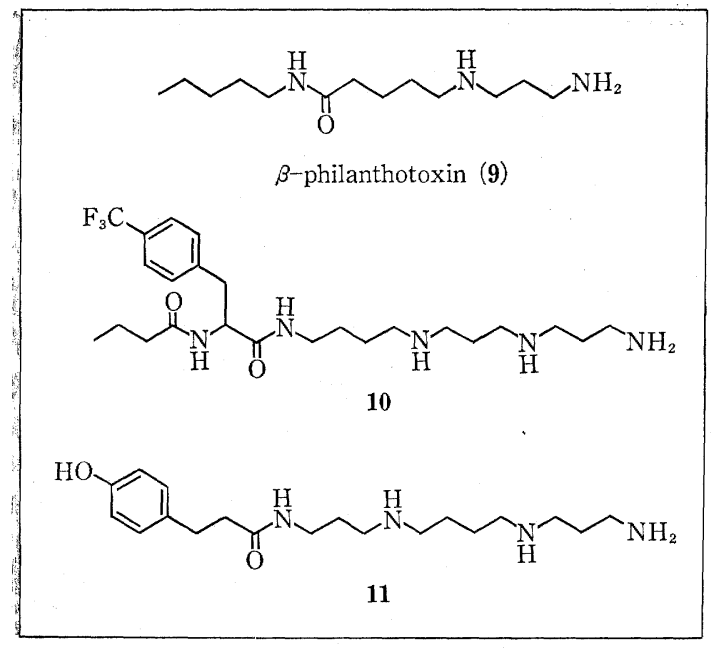

图 4
2.5 倍の活性を示すことを見つけている(16).

構造一活性相関は, 他にも 2 つの゙ループが独立に行 なっている. Benson らは, 33 個の誘導体について, イ エバエ幼虫の神経筋を用いてテストし，バッタ神経筋と ほぼ同様の傾向を示す結果を得た ${ }^{(17)}$. Blagbrough ら は, PhTX, argiotoxin を殺虫剛, 神経系医薬品のリー ド化合物として位置づけ，構造-活性相関を調べた結果， PhTX-343 のチロシンのアンルアミノ基を取り去った 化合物 11 が約 4 倍程度強い活性を示すことを見つけ たとして，これらアシルポリアミン骨格を持つ化合物 とレセプターの相互作用について考察している(18).

カリウドバチが麻痺性の毒を持つことを初めて明らか にしたのは J.H. ファーブルで，その様子は，有名な 『昆虫記』飞詳しく，乙かも生き生きと描かれている、し かし，その毒成分の構造がわかったのは，それから 130 年余りも過ぎてからであった、それはちょらど，グルタ ミン酸レセプターをめぐる研究が活発になってきたとき にあたり，この八チ毒は，今や，化学・生物学・農学・ 医学の各方面から大きな注目を集めるに至っている。こ の種の八チは, 世界中に数千から数万種生息していると いわれまだまだ違った性質の神経毒が得られる可能性 もある.いずれにしても，各方面への今後の発展が期待 される，八チの麻痺毒の研究が，このような展開になろ らとは, ファーブルも夢にも思わなかったにちがいな い.

1) 中嶋睴躬: 化学亡工業, 37, 745 (1984).

2) W.Spanjer, T.E.May, T.Piek \& N. de Haan : Comp. Biochem. Physiol., 71 c, 149 (1982).

3) A. T. Eldefrawi, M. E. Eldefrawi, K. Konno, K. Mansour, K. Nakanishi, E. Oltz \& P. N. R. Usherwood: Proc. Natl. Acad. Sci. USA, 85, 4910 (1988).

4) T.Piek, R. H. Fokkens, H. Karst, C. Kruk, A. Lind, J. van Marle, T. Nakajima, N.M.M.Nibbering, H. Shinozaki, W.Spanjer \& Y.C. Tong : "Neurotox '88 : Molecular Basis of Drug \& Pesticide Action”, ed. by G. G. Lunt, Elsevier, Amsterdam, 1988, p. 61.

5) K. Nakanishi, R. Goodnow, K. Konno, M. Niwa, R. Bukownik, T.A. Kallimopoulos, P. Usherwood, A.T. Eldefrawi \& M.E. Eldefrawi : Pure \& Appl. Chem., 62, 1223 (1990).

6) G. Chiles, S.-K. Choi, A. Eldefrawi, M. Eldefrawi, S. Fushiya, R. Goodnow, Jr., A. Kalivretenos, K. Nakanishi \& P. Usherwood : “Neurotox'91 : Molecular Basis of Drug \& Pesticide Action”, ed. by I. R. Duce, Elsevier, Amsterdam, 1991, p. 3. 
7) K. Nakanishi, S.-K. Choi, D. Hwang, K. Lerro, M. Orlando \& A.G. Kalivretenos: Pure \& Appl. Chem., in press.

8) H.E. エバンス, K.M. オニール：日経サイエンス, 1991 年 10 月号, p. 82 .

9) H. Jackson \& P. N. R. Usherwood : Trends in Neurosci., 11, 278 (1988).

10) 中鴆腪躬, 川合述史: 化学々生物, 27, 555 (1989).

11) S. Nakanishi : Science, 258, 597 (1992).

12) S.-K. Choi, K. Nakanishi \& P.N.R. Usherwood: Tetrahedron, 49, 5777 (1993).

13) J.-L. Galzi, F. Revah, A. Besis \& J.-L. Changeux, Annu. Rev. Pharmacol., 31, 37 (1991).

14) S.-K. Choi, R. A. Goodnow, A. Kalivretenos, G.W. Chiles, S. Fushiya \& K. Nakanishi : Tetrahedron, 48,
4793 (1992).

15) H. Karst, R. H. Fokkens, N. de Haan, G. Heuver, B. Hue, C. Kruk, N. M. M. Nibbering, T. Piek, W. Spanjer, Y.C. Tong \& W. van der Vliet: Comp. Biochem. Physiol., 97 c, 317 (1990).

16) H. Karst, T. Piek, J. Van Marle, A. Lind \& J. Van Weeren-Kramer : Comp. Biochem. Physiol., 98 c, 471 (1991).

17) J.A. Benson, F. Schürmam, L. Kaufman, L. Gsell \& T. Piek : Comp. Biochem. Physiol., 102 c, 267 (1992).

18) I.S. Blagbrough, P.T.H. Brackley, M. Bruce, B.W. Bycroft, A. J. Mather, S. Millington, H. L. Sudan \& P. N. R. Usherwood: Toxicon, 30, 303 (1992).

(紺野勝弘, 帝京大学薬学部)

\begin{tabular}{|c|c|c|c|c|}
\hline & プ & 口 & フ & ル \\
\hline 清水 博之 (Hiroyuki Shimizu) 昭和 & \multirow{7}{*}{\multicolumn{4}{|c|}{ 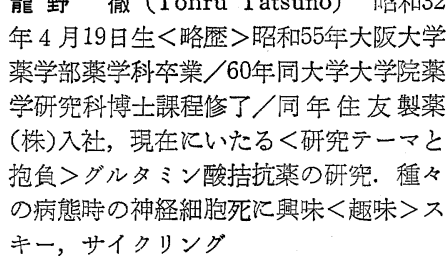 }} \\
\hline 39年11月14日生＜略歷>平成元年京都大 & & & & \\
\hline 学農学部農学科卒業／同年農林水産省農 & & & & \\
\hline 業生物資源研究所勤務後, 北陸農業試験 & & & & \\
\hline 場稲育種研究室研究員, 現在にいたる & & & & \\
\hline <研究テーマと抱負 >水稲の育種. 生物 & & & & \\
\hline $\begin{array}{l}\text { 工学的手法を用いた稲育種法の開発とそ } \\
\text { の利用く趣味〉ドライブ, スキー }\end{array}$ & & & & \\
\hline
\end{tabular}

新名 惇彦 (Atsuhiko Shinmyo) 昭和 17年 8 月27日生<略歷 > 1965年大阪大学 工学部醴酵工学科卒業/1970年同大学大 学院工学研究科博士課程修了（醴酵工 学), 工博, 同工学部助手 $/ 1977 \sim 78$ 年米 国 MIT 研究員 / 1985年大阪大学工学部 助教授 $/ 1992$ 年同教授，現在にいたる く研究テーマと抱負〉植物の遺伝子発現 制御機構を種々の遺伝子について明らか にし，それぞれの制御ニニットをタバコ 培養細胞に持ちこみ, タバニで有用蛋白 質生産を最適に制御するシステムを作る ことく趣味>围基, 音楽

田中 祥裕 (Hiroyasu Tanaka) 昭和 37 年11月25日生 $<$ 略歴 $>$ 昭和60年広島大 学医学部総合薬学科卒業 $/ 62$ 年同大学大 学院医学研究科博士課程前期修了/同年 住友製薬(株)入社，現在にいたるく研究 テーマと抱負>グルタミン酸受容体の研 究. 興奮性アミノ酸以外にグリアーニニー ロンの相互作用と脳機能に興味く趣味〉 モータースポーツの観戦, カラオケ, J

リーグ（サンフレッチニ広島）
塚本佐知子 (Sachiko Tsukamoto) 昭 和35年 4 月 18 日生 <略歴>昭和58年北海 道大学薬学部䑾薬化学科卒業 $/ 60$ 年同大 学大学院楽学研究科修士課程修了 $/ 61$ 年 同薬学部教務職員(文部技官) $/ 63$ 年米国 ロードアイランド大学薬学部に博士研究 員と乙て留学( 平成 2 年) /平成 4 年新 技術事業団伏谷着生機構プロジェクト研 究員, 現在にいたる. 昭和63年薬博（北 海道大学) 〈研究テーマと抱負>海洋の 付着生物幼生の付着・变態湆影を与響を る化合物の探索く趣味〉映画を観るこ と，映画の話をすること

森 裕司 (Yuji Mori) 炤和28年11月 21 日生 $<$ 略歷 $>$ 昭和 52 年東京大学農学部 畜産獣医学科卒業 $/ 57$ 年同大学大学院農 学系研究科博士課程修了/同年東京農工 大学農学部助手 $/ 62$ 年同助授教/平成 2 年東京大学農学部助教授 (獣医動物行動 学), 現在にいたるく研究テーマと抱負> 大型哺乳類にお汓る神経行動学く趣味> 温泉と銘酒の探訪
山下かなへ (Kanae Yamashita) 昭和 12年12月15日生＜略歴>昭和35年就茶の 水女子大学家政学部食物学科卒業 $/ 43$ 年 名古屋大学大学院農学研究科博士課积修 了/ 49 年名古屋市立大学医学部生理学教 室助手 $/ 52$ 年椙山女学園大学家政学部食 物学科助教授 $/ 59$ 年同教授, 現在にいた るく研究テーマと抱角〉「食品抗酸化物 質の老化抑制効果」をラット, SAMP-1 を用いてビタミン Eとの関連を中心に研 究<趣味>山歩き, 旅行

山田秀明 (Hideaki Yamada) 昭和 4 年 3 月 11 日生 $<$ 略歴 $>$ 昭和 28 年京都大学 農学部農芸化学科卒業/同年同農学部助 手 $/ 39$ 年同食糧科学研究所助教授 $/ 46$ 年 同教授 $/ 52$ 年同農学部教授 /平成 4 年同 大学名誉教授, 関西大学工学部教授, 現 在にいたるく研究テーマと抱負 >生体触 媒の開発と応用く趣味>やきもの, 古美 術鑑賞, スポーツ (ゴルフ)

山本(前田)万里 (Mari Maeda Yamamoto）昭和36年 2 月 19 日生 $<$ 略歷 $>$ 昭 和59年千葉大学園芸学部農芸化学科卒業 $/ 61$ 年同大学大学院園芸学研究科修士課 程修了/同年農林水産省中国農業試験場 研究員 $/$ 平成 4 年同省野菜・茶業試験場 研究員 /同年農博(九州大学), 現在にい たるく研究テーマと抱負〉食品成分，特 に多糖類の生体調節機能<趣味 $>$ 料理, 合唱 